\title{
Konsep Dasar Ilmu Pengetahuan Sosial dalam Dunia Pendidikan
}

\author{
Basic Concepts of Social Science in Education \\ Laila Nurjanah ${ }^{1 凶}$, Sri Handayani ${ }^{2}$, Rudy Gunawan ${ }^{3}$ \\ $1 \bowtie 23$ Pascasarjana Universitas Muhammadiyah Prof. Dr. Hamka \\ E-mail: laila22oke@gmail.com ${ }^{凶}$
}

Diterima: 9 Juli 2021 | Direvisi: 30 November 2021 | Diterbitkan: 30 November 2021

ARTICLE INFO

Keywords:

Social Science,

Education,

Knowledge.
Kata Kunci:

IImu Pengetahuan Sosial,

Pendidikan,

Pengetahuan.
ABSTRACT

Social Studies is the embodiment of an interdisciplinary approach to the social sciences. By integrating various branches of science, such as sociology, cultural anthropology, psychology, history, geography, economics, political science and human ecology, which are formulated in such a way that they can be connected and complement each other. Therefore, this article aims to find out more about the basic concepts of social studies contained in the world of education. The method used to collect data in this study is a qualitative method with a literature study approach. This study was conducted by collecting various kinds of data from books, magazines, newspapers, articles, books, documents and archives that were considered relevant. From this research, it is known that Social Science (IPS) is a study of knowledge that includes four dimensions, namely the knowledge dimension, the skill dimension, the values and attitudes dimension, and the action dimension. Then in the scope of social studies education is formed from a combination of history, geography, sociology and economics.

IPS adalah perwujudan dari suatu pendekatan interdisipliner dari ilmu sosial. Dengan mengintegrasikan berbagai cabang ilmu seperti, sosiologi, antropologi budaya, psikologi, sejarah, geografi, ekonomi, ilmu politik dan ekologi manusia yang diformulasikan sedemikian rupa agar dapat saling terhubung dan melengkapi satu sama lain. Oleh sebab itu artikel ini bertujuan untuk mengetahui lebih jauh mengenai konsep dasar IPS yang tertuang dalam dunia pendidikan. Metode yang digunakan untuk mengumpulkan data dalam penelitian ini adalah metode kualitatif dengan pendekatan studi kepustakaan. Studi ini dilakukan dengan cara mengumpulkan berbagai macam data dari buku, majalah, koran, artikel, kitab, dokumen dan arsip yang dianggap relevan. Dari penelitian ini diketahui bahwa IImu pengetahuan sosial (IPS) merupakan suatu kajian pengetahuan yang mencakup empat dimensi yaitu dimensi pengetahuan, dimensi keterampilan, dimensi nilai dan sikap, dimensi tindakan. Kemudian dalam cakupan pendidikan IPS terbentuk dari gabungan antara ilmu sejarah, geografi, sosiologi dan ekonomi.

\section{PENDAHULUAN}

Menurut Abdul Kadir, dkk (2012: 59)

Pendidikan dalam arti luas adalah segala pengalaman belajar yang berlangsung dalam segala lingkungan dan sepanjang hidup. Pendidikan merupakan proses kegiatan belajar mengajar yang

membentuk

atau mengembangkan suatu pengetahuan, keterampilan hingga pembentukan karakter yang diturunkan dari generasi ke generasi berikutnya. Sekolah menjalankan aktivitasaktivitas pendidikannya berdasarkan 
Nurjanah, Handayani \& Gunawan, 2021, Konsep Dasar IImu . . .

karakteristik, kebutuhan, dan situasi sekolah. Hakikat aktivitas berbasis sekolah ini amat penting untuk meningkatkan kualitas pendidikan (Nurholis 2008: 56). Selanjutnya, sekolah merupakan salah satu lembaga pendidikan yang memiliki peranan penting untuk dapat melaksanakan tujuan pendidikan nasional.

Terkait dengan tujuan pendidikan tersebut, Ilmu Pengetahuan Sosial adalah mata pelajaran di sekolah yang di desain atas dasar fenomena, masalah dan realitas sosial dengan pendekatan interdisipliner yang melibatkan berbagai cabang ilmu-ilmu sosial dan humaniora seperti kewarganegaraan, sejarah, geografi, ekonomi, sosiologi, antropologi, pendidikan. Karena itu, IPS dapat dikatakan sebagai studi mengenai perpaduan antara ilmu-ilmu dalam rumpun ilmuilmu sosial dan juga humaniora untuk melahirkan pelaku-pelaku sosial yang dapat berpartisipasi dalam memecahkan masalahmasalah sosio kebangsaan. Bahan kajiannya menyangkut peristiwa, seperangkat fakta, konsep dan generalisasi yang berkait dengan isu-isu aktual, gejala danmasalah-masalah atau realitas sosial serta potensi daerah.

Sebutan IPS (IImu Pengetahuan Sosial) di Indonesia adalah sebuah kesepakatan untuk menunjuk istilah lain dari social studies. Menunjuk sifat keterpaduan dari ilmu-ilmu sosial atau integrated social sciences. Jadi sifat keterpaduan itu mestinya menjadi ciri pokok mata kajian yang disebut IPS. IPS adalah studi integratif tentang kehidupan manusia dalam berbagai dimensi ruang dan waktu dengan segala aktivitasnya. Dalam rumusan yang lain, IPS merupakan kajian yang terkait dengan kehidupan sosial kemasyarakatan berserta lingkungannya untuk kepentingan pendidikan dan pembentukan para pelaku sosial (Edy Surahman, 2017).

Dalam artikel ini akan dibahas tentang konsep dasar ilmu sosial pada IPS. IImu sosial berhubungan dengan IImu Pengetahuan Sosial, karena IPS merupakan paduan dari ilmuilmu sosial yang disederhanakan. Melalui ilmuilmu sosial, manusia tidak hanya mengetahui tentang cara bersosialisasi dan berinteraksi di dalam masyarakat tetapi juga dapat mengetahui konsep dasar ilmu- ilmu sosial, yaitu sosiologi, geografi, ekonomi, ilmu politik, antropologi, sejarah, dan psikologi sosial.

\section{METODE}

Demi mendapatkan hasil yang valid dalam penelitian ini maka metode penelitian yang digunakan untuk mengumpulkan data dalam penelitian ini yaitu metode kualitatif dengan menggunakan instrumen studi dokumen atau studi pustaka (Absor, 2020). Studi kepustakaan merupakan sebuah metode yang digunakan dalam penelitian dengan memanfaatkan penggalian informasi melalui buku, artikel, majalah, arsip dan dokumen lainnya yang dianggap relevan dengan topik yang diambil (Moleong, 2018).

Setelah melakukan pencarian data melalui berbagai literatur tersebut, tahap selanjutnya yang dilakukan yakni memilah sumber mana yang tepat untuk digunakan dalam mengungkap realitas topik penelitian dan dijadikan dasar teori penulisan. Kemudian langkah selanjutnya peneliti melakukan verifikasi atau penarikan kesimpulan atas sumber-sumber yang telah didapatkan dan menuliskannya dalam artikel.

\section{HASIL DAN PEMBAHASAN}




\section{Konsep Ilmu Pengetahuan Sosial}

Pada masa lampau setiap ilmu termasuk ke dalam ruang lingkup filsafat karena tidak dilakukan kajian secara mendalam menggunakan prosedur khusus dari ilmu yang ada. Akan tetapi seiring berjalannya waktu, ilmu mengalami perkembangan, baik dari metode, prosedur atau kajian di dalamnya. Misalnya, dalam ranah ilmu alam terbagi ke dalam beberapa sub ilmu yaitu kimia, fisika, biologi. Jika ditelisik lagi ilmu ini kemudian dikelompokan lagi menjadi lebih khusus seperti bioteknologi, geofisika dan sebagainya. Sedangkan dalam ranah ilmu sosial ilmu dibagi ke dalam beberapa disiplin ilmu, diantaranya yaitu, sosiologi, antropologi, geografi, ekonomi, ilmu politik dan psikologi (Karim, 2014).

Perkembangan ilmu pengetahuan sendiri tidak terlepas dari manfaatnya yang besar dalam mempermudah kehidupan manusia, termasuk juga IPS. Walau tidak terlihat secara nyata layaknyaa ilmu alam yang menciptakan teknologi. IImu sosial berguna untuk memberikan bekal pengetahuan agar manusia dapat menghadapi masalah-masalah dalam lingkungan masyarakat. Karena masalah yang dihadapi oleh masyarakat bersifat kompleks dan selalu berkembang, maka dari itu peran ilmuilmu sosial sangat penting disini. Walaupun begitu karna bidang ilmu sosial begitu banyak dan membutuhkan waktu lama untuk mempelajarinya, maka lahirlah sebuah gagasan untuk menyatukan beberapa ilmu sosial tersebut dan digunakan dalam pengajaran di sekolah demi membekali masyarakat. Di Indonesia sendiri hal ini terwujud dengan lahirnya kurikulum 1975 dengan mata pelajaran bernama pengajaran ilmu pengetahuan sosial (Wahana, 2016).

IPS adalah terjemahan dari Sosial Studies yang ada di Amerika yang berarti penelaahan atau kajian tentang masyarakat. IPS merupakan suatu program pendidikan dan bukan subdisiplin ilmu tersendiri, sehingga tidak akan ditemukan baik dalam nomenklatur filsafat ilmu, disiplin ilmu-ilmu sosial (social science), maupun ilmu pendidikan (Gunawan, 2016). Pengembangan IPS di Indonesia banyak mengambil ide-ide dasar dari pendapatpendapat yang dikembangkan di Amerika Serikat tersebut dengan tujuan, materi dan penanganannya dikembangkan sendiri sesuai dengan tujuan nasional dan aspirasi masyarakat Indonesia. Hal ini dilakukan pada realitas, gejala dan problem sosial yang menjadi kajian IPS yang tidak sama dengan negara-negara lain.

Berikut ini pengertian IPS menurut ahli pendidikan dan ahli IPS di Indonesia: Pertama, Cokrodikardjo (2009) mengemukakan bahwa IPS adalah perwujudan dari suatu pendekatan interdisipliner dari ilmu sosial yang mengintegrasikan berbagai macam cabang ilmu sosial seperti sosiologi, antropologi budaya, psikologi, sejarah, geografi, ekonomi, ilmu politik dan ekologi manusia, yang diformulasikan untuk tujuan instruksional dengan materi yang disederhanakan agar mudah dipelajari. Kedua, Soemantri dalam Miftahuddin (2016) berpendapat bahwa IPS merupakan pelajaran ilmu-ilmu sosial yang disederhanakan untuk pendidikan tingkat SD, SLTP, dan SLTA. Kesimpulan yang dapat ditarik dari definisidefinisi tersebut IPS adalah studi sosial yang mengangkat konsep-konsep, teori-teori ilmu 
sosial secara terintegrasi guna memahami, mempelajari, memikirkan pemecahan masalahmasalah yang ada di masyarakat, sehingga memberi kepuasan bagi personal dan bagi masyarakat secara keseluruhan, dengan tujuan mendidik anak menjadi warga negara yang baik.

Dengan demikian maka dapat dipahami bahwa mata pelajaran IPS bertujuan agar peserta didik memiliki kemampuan mengenal konsep-konsep yang berkaitan dengan kehidupan, masyarakat dan lingkungannya, memiliki kemampuan dasar untuk berpikir logis dan kritis, rasa ingin tahu, inkuiri memecahkan masalah, dan keterampilan dalam kehidupan sosial, memiliki komitmen dan kesadaran terhadap nilai-nilai sosial dan kemanusiaan, memiliki kemampuan berkomunikasi, bekerjasama dan berkompetisi dalam masyarakat yang majemuk, di tingkat lokal, nasional, dan global. Lebih dari itu IPS juga berguna untuk membina anak didik menjadi warga negara yang baik, memiliki pengetahuan dan memiliki kepedulian sosial yang berguna bagi dirinya serta bagi masyarakat dan negara.

\section{Landasan Konseptual Pembelajaran IPS}

IPS sebagai salah satu mata pelajaran di sekolah sudah sepantasnya memiliki fondasi dasar dalam pengembangannya, baik sebagai mata pelajaran ataupun disiplin ilmu. Dalam hal ini landasan berperan dalam memberikan sumbangsih gagasan-gagasan dasar terkait pengembangan metodologi ataupun struktur pemanfaat pembelajaran IPS. Secara garis besar landasan-landasan yang menjadi dasar berdirinya IPS sebagai disiplin ilmu terdiri dari:

\section{a. Landasan filosofis}

Landasan filosofis IPS dibagi ke dalam tiga unsur yakni ontologis, epistemologis, aksiologis. Unsur ontologis berfungsi menentukan objek kajian atau domain yang akan digunakan sebagai pokok dan dimensi pengembangan IPS sebagai sebuah disiplin ilmu. Unsur epistemologis adalah cara, proses, atau metode membangun dan mengembangkan IPS hingga menentukan pengetahuan mana yang dianggap benar, sah, valid, atau terpercaya. Unsur aksiologis bermanfaat dalam mengkaji tujuan IPS sebagai pendidikan disiplin ilmu (Muniroh, 2020).

\section{b. Landasan ideologis}

Landasan ideologis yaitu sebuah landasan yang berguna sebagai gagasan dasar dalam memberi pertimbangan dan menjawab pertanyaan terkait hubungan antara das sein PIPS sebagai pendidikan dan disiplin ilmu dan das sollen PIPS serta relevansinya terhadap teori- teori pendidikan yang mengandung hakikat moral, etika, dan norma-norma yang berguna dalam memaksimalkan pembelajaran IPS (Endayani, 2018).

\section{c. Landasan sosiologis}

Landasan ini berfungsi sebagai landasan dasar membangun cita-cita, aspirasi, kekuatan, dan kebutuhan IPS sebagai sebuah disiplin ilmu di masa yang akan datang melalui serangkaian interaksi sosial (Endayani, 2017).

\section{d. Landasan antropologis}


Memberikan landasan mendasar terkait penentuan sistem, struktur dan pola pendidikan sehingga relevan dengan berbagai unsur kebudayaan yang ada dalam suatu lingkungan masyarakat yang kompleks (Endayani, 2017).

\section{e. Landasan kemanusian}

Landasan ini memfokuskan kepada pemenuhan kriteria ideal manusia sebagai tujuan akhir pendidikan IPS di kalangan masyarakat.

\section{f. Landasan politis}

Landasan ini lebih mengarah pada penentuan arah kebijakan politik yang berguna untuk melahirkan sistem pemerintahan yang ideal bagi masyarakat melalui pendidikan IPS di sekolah (Muniroh, 2020).

\section{g. Landasan psikologis}

Landasan psikologis lebih menekankan kepada pembentukan sudut pandang guru terhadap siswa melalui perspektif psikologis dengan tujuan guru dapat mengambil sikap yang bijak dalam menyikapi permasalah yang terjadi di kelas ataupun sekedar memahami tingkah laku peserta didik serta menentukan cara yang tepat dalam memberikan materi kepada siswa yang ada.

\section{h. Landasan religius}

Sesuai namanya, landasan ini menekankan pada pembenahan sistem mendasar tentang religiusitas dalam diri peserta didik demi membentuk norma, etika, moral dan nilai-nilai kehidupan menuju arah yang lebih baik sesuai pedoman agama (Nofiaturrahmah, 2015).

Dengan demikian berbagai macam landasan tersebut berguna untuk membangun sistem pembelajaran IPS agar menjadi jauh lebih kompleks dan tepat dalam menyikapi berbagai fenomena sosial yang terjadi di lingkungan masyarakat. Dengan tujuan mampu menjadikan IPS sebagai sebuah ilmu yang berguna dalam mengembangkan kepekaan peserta didik terhadap lingkungan sekitar agar menjadi manusia yang berguna terhadap nusa dan bangsa.

\section{Disiplin IImu yang Membangun IPS dî Dunia Pendidikan}

IImu Pengetahuan Sosial berhubungan dengan ilmu-ilmu sosial karena IPS dikembangkan ke dalam beberapa ilmu-ilmu sosial. Maka dari itu hampir setiap cabang ilmu yang mengkaji tentang masyarakat terhubung dengan IPS, namun dalam dunia pendidikan hanya beberapa disiplin ilmu saja yang menjadi dasar berdirinya IPS. Bidang ilmu tersebut antara lain:

\section{a. Konsep Dasar Sosiologi}

Sosiologi secara etimologi berasal dari bahasa latin yakni socius yang berarti teman, keluarga, masyarakat dan logos yang berarti ilmu. Dengan demikian maka sosiologi dapat diartikan sebagai ilmu yang mempelajari tentang masyarakat. Sosiologi sendiri masuk sebagai salah satu ilmu rumpun sosial, ketika Aguste Comte pada 1842 mencetuskannya. Setelah itu istilah ini kemudian dilanjutkan oleh Emile Durkheim. 
Nurjanah, Handayani \& Gunawan, 2021, Konsep Dasar IImu . . .

Sebagai sebuah ilmu yang mengkaji masyarakat, sosiologi memiliki objek studi, diantaranya yaitu: 1) Manusia yang hidup bersama di dalam suatu lingkungan masyarakat dalam waktu yang relatif lama serta terus menjalin komunikasi secara intens. Baik melalui tutur kata, sikap ataupun perilaku sehingga terjalinlah hubungan yang kuat antar manusia tersebut, baik yang berdampak negatif ataupun positif. 2) Manusia yang satu dengan manusia yang lain menjalin keterikatan yang tidak dapat dipisahkan. 3) Memiliki sistem hidup bersama yang berujung pada terlahirnya berbagai macam norma, adat istiadat, budaya yang kemudian mengikat masyarakat tersebut (Lubis, 2018).

Dalam bidang kajiannya sendiri, sosiologi memiliki ruang lingkup yang luas. Hal ini didasari karena perkembangan zaman dan kondisi manusia yang bersifat terbuka dan selalu berkembang. Secara garis besar ruang lingkup sosiologi dibedakan menjadi beberapa sub disiplin ilmu yaitu: sosiologi pedesaan, sosiologi perkotaan, sosiologi medis, sosiologi seni, sosiologi industri, sosiologi pendidikan dan masih banyak lagi.

Sosiologi yang termasuk dalam rumpun ilmu sosial umumnya dianggap sebagai sebuah ilmu murni "pure sciene" yang pada sistem pengaplikasiaanya bersifat abstrak dan tak terlihat begitu nyata. Berbeda dengan rumpun ilmu alam yang lebih bersifat terapan "applied sciene" dan hasilnya terlihat secara nyata. Maka dari itu hal yang dapat diperoleh dari mempelajari ilmu sosiologi berupa peningkatan pemahaman manusia dalam kehidupan bermasyarakat supaya manusia tersebut sadar akan tempatnya dan dapat berkonstribusi secara positif di lingkungan sekitar. Selain itu juga dengan mempelajari sosiologi diharapkan manusia dapat beradaptasi dengan mudah dilingkungan yang mereka tinggali. Kemudian yang terpenting manusia tersebut dapat bersikap secara toleran antar sesama manusia baik terhadap persoalan agama ataupun budaya.

\section{b. Konsep Dasar Antropologi}

Selama hidup di dunia manusia terus berkembang dan menciptakan berbagai macam hal dengan kemampuan imajinasi yang mereka miliki, hingga sampailah pada suatu tahap dimana manusia tersebut melahirkan kebudayaan dan peradaban. Keunikan dari setiap peradaban yang tercipta karena faktor alam dan juga imajinasi manusia tersebut, membuat segelintir ilmuan tertarik untuk menelaahnya secara mendalam. Atas dasar tersebutlah maka hadir ilmu yang dikenal sekarang sebagai antropologi.

Antropologi berasal dari bahasa Yunani yang terdiri dari kata antrophos yang berarti manusia dan logos yang bermakna ilmu. Kemudian dalam perkembangannya istilah sosiologi memiliki definisi yang berbeda. Misalnya, menurut Astawa dalam Lubis (2018) antropologi merupakan sebuah ilmu yang menelaah perilaku manusia dalam ruang lingkup budaya, suku, dan adat istiadat. Oleh sebab itu secara garis besar, antropologi memiliki tiga tujuan utama, yakni: 1) Mengkaji sedetailnya cara hidup manusia dari berbagai kelompok dan menganalisis kondisi fisik dan karakter yang mereka miliki. 
2) Memahami cara hidup manusia sebagai sebuah kelompok yang dapat bekerjasama dengan baik sehingga menciptakan berbagai macam kebudayaan. 3) Mencari fokus utama berupa prinsip hidup manusia tersebut dan bagaimana cara dan gaya mereka hidup.

Berdasarkan pemaparan di atas maka dapat dipahami bahwa dengan mempelajari antropologi manusia setidaknya mendapatkan empat nilai guna, yang terdiri dari: 1) Mengetahui perilaku kehidupan manusia dalam berinteraksi di lingkungan masyarakat biak yang bersifat universal maupun hanya mencakup suku bangsa tertentu. 2) Memahami peran dan kedudukan yang disandang dalam suatu lingkungan masyarakat. 3) Memperkaya pengetahuan seputar kehidupan manusi adi segala penjuru dunia serta adat dan kebiasaan yang mereka miliki sesuai dengan karakteristik daerahnya. Hal inilah yang kemudian melahirkan rasa toleransi dalam diri manusia yang mempelajari antropologi. 4) Mengetahui berbagai macam problematika yang ada di lingkungan masyarakat sehingga dapat dijadikan pedoman dalam menyelesaikan suatu permasalahan.

\section{c. Konsep Dasar Ekonomi}

Kajian konsep dasar IImu ekonomi sering kali dikenal dengan bapak ekonomi yakni Adam Smith, bahwa Adam Smith mendefinisikan ilmu ekonomi merupakan sebuah penyelidikan kedalam sifat dan penyebab kekayaan bangsa-bangsa. Secara bahasa ekonomi berasal dari bahasa Yunani yakni oikonamos atau oikonomia yang berarti manajemen urusan rumah tangga, khususnya penyediaan dan administrasi.

pendapatan. ilmu ekonomi juga merupakan ilmu yang mempelajari kebutuhan manusia dan upayaupaya untuk memenuhi kebutuhan manusia guna mencapai kemakmuran. Menurut Lubis (2018) Objek kajian ilmu ekonomi ialah keseluruhan kegiatan perekonomian manusia. Keluasan kajian tersebut menyebabkan ruang lingkup dalam bidang ekonomi dikenal menjadi dua yaitu bersifat mikro dan bersifat makro.

Beberapa manfaat belajar ilmu ekonomi, antara lain: 1) Membantu Cara Berpikir yang Tepat dalam Pengambilan Keputusan Pikiran adalah harta yang sangat berharga dalam diri manusia. Manusia dengan pikirannya mampu menganalisis, melakukan penilaian terhadap benar-salah serta baik-buruk, untuk kemudian menentukan pilihan terhadapnya. Kemampuan ini pula yang menjadikan manusia dapat mempertahankan keberadaannya untuk ada pada puncak ekosistem di bumi ini. Seiring perkembangan zaman, manusia juga terus-menerus berusaha untuk meningkatkan kualitas hidupnya. Berbagai metode dan teknik berpikir dalam ilmu ekonomi akan semakin meningkatkan kemampuan berpikir dan mengambil keputusan dari setiap perbuatan yang dilakukan. 2) Membantu Memahami Masyarakat Manusia tidak bisa hidup tanpa orang lain, karena manusia adalah makhluk sosial. Berinteraksi adalah hal yang tidka bisa dihentikan. Sedangkan menurut ilmu ekonomi, interaksi manusia terjadi lewat pertukaran atau yang disebut dengan pasar. 
Nurjanah, Handayani \& Gunawan, 2021, Konsep Dasar IImu . . .

Diajarkan dalam sejarah-sejarah ekonomi, bahwa manusia berupaya mengatasi kelangkaan melalui pertukuran tersebut. Peradaban pun kian berkembang dan sistem kemasyarakatan juga semakin maju. Melalui ilmu ekonomi, manusia dapat belajar banyak dan memahami berbagai peristiwa penting dalam sejarah perekonomian dunia, seperti revolusi industri di Inggris dan revolusi politik di Perancis, serta peristiwa-peristiwa bersejarah penting lainnya. 3) Membantu Pemahaman tehadap masalah-masalah global pada setiap tingkat hidup selalu ada kelangkaan yang terjadi dan harus dihadapi, mulai dari individu, keluarga, masyarakat desa, kota, negara bahkan dunia. Pada tingkat internasional, jarang sekali terjadi interaksi ekonomi antarindividu yang secara langsung demi kepentingan pribadi. Individu yang berinteraksi lebih sering mewakili kepentingan- kepentingan kelompoknya (negara maupun perusahaan). Apa yang dilakukan oleh mereka walaupun terlihat baik bagi kelompok atau negara lain, namun sebenarnya lebih kepada pertimbangan kepentingan kelompok atau negara mereka sendiri.

\section{d. Konsep Dasar Geografi}

Seacara bahasa Geografi berasal dari kata Geo dan Graphein yang berarti bumi dan tulisan, untuk itu ilmu geografi membahas tentang ilmu yang mempelajari bumi. Geografi berasal dari bahasa Yunani, yaitu geo yang berarti bumi dan graphein yang berarti lukisan atau tulisan. Menurut pengertian yang dikemukakan oleh Eratosthenes, geographika berarti tulisan tentang bumi. Pengertian bumi dalam geografi tersebut, tidak hanya berkenaan dengan fisik alamiah bumi saja, melainkan juga meliputi segala gejala dan proses alamnya, maupun gejala dan proses kehidupannya. Oleh karena itu, dalam hal gejala dan proses kehidupan melibatkan kehidupan tumbuh-tumbuhan, binatang, dan manusia sebagai penghuni bumi tersebut. geografi secara makro dapat dikelompokkan dalam dua subdisiplin, yaitu: Geografi fisik dan Geografi manusia.

Manfaat Mempelajari Geografi Setiap lapisan yang dipelajari dalam geografi baik atmosfer, hidrosfer, biosfer, litosfer maupun antrhoposfer selalu mengandung hakikat nilai atau manfaat. Hal ini berarti bahwa keterlibatan georafi dengan aspek-aspek bidang kajiannya menjadikan cabang ilmu ini berfungsi tidak saja untuk menjelaskan, namun juga meramal, dan mengontrol yang diapalikasikan ke dalam perencanaan dan pengembangan wilayah sebagai geografi terapan.

Berkenaan dengan itu, secara sederhana dapat dikemukakan bahwa nilai guna geografi berkaitan dengan tiga hal, yakni: 1) Subjektivisme, yaitu kegunaannya bagi manusia. Contoh: jika seorang geograf ingin menjadikan suatu wilayah tertentu sebagai daerah pemukiman, maka terlebih dahulu melakukan pengkajian tentang jenis tanah, morfologi, aksebilitas, kondisi air tanah dan kondisi sosial pada suatu wilayah tertentu. 2) Objektivisme logis, yaitu yang bersifat empiris baik melalui hasil percobaan, pengukuran. atau yang lainnya. Contoh: melihat letak geografis Indonesia yang dilalui oleh jalur 
sirkum mediteran, seberapa tinggi tingkat kerawanan bencana alam letusan gunung api di indonesia, dan lain-lain. 3) Nilai etika dan estetika yang berkenaan dengan interaksi manusia dengan lingkungannya. Misalnya jika tidak beretika dalam menggunakan wilayah maka bisa saja terjadi bencana alam, seperti banjir, tanah longsor, dan lainlain (Segara, Pasya, \& Maryani, 2016).

\section{e. Konsep Dasar Sejarah}

Kajian Ilmu sejarah sangat menjadi sebuah kajian jejak dan sejarah yang terjadi memuat kehidupan manusia dimasa lalu, sekarang dan masa yang akan datang. Istilah sejarah berasal dari bahasa Arab yakni syajaratun (dibaca syajarah), yang artinya pohoh kayu. Pengertian pohon kayu disini adalah adanya suatu kejadian, perkembangan atau pertumbuhan tentang suatu hal (peristiwa) dalam suatu kesinambungan (kontinuitas). History yang bersumber dari bahasa Yunani kuno historia yang berarti belajar dengan cara bertanyatanya. Kata historia diartikan sebagai telaahan mengenai gejala-gejala (terutama hal ihwal manusia) dalam urutan kronologis. Setelah menelusuri arti sejarah yang dikaitkan dengan arti syajarah dan dihubungkan dengan kata history, bersumber dari kata historia dapat disimpulkan bahwa sejarah ialah cerita atau kejadian yang benarbenar telah terjadi pada masa lampau (Kuntowijoyo, 2013).

Dilihat dari ruang lingkupnya, terutama pembagian sejarah secara tematik, sejarah memiliki cakupan yang sangat luas. Madjid \&
Wahyudhi (2014) mengelompokkan dalam belasan jenis sejarah yaitu sejarah sosial, sejarah ekonomi, sejarah kebudayaan, sejarah demografi, sejarah politik, sejarah kebudayaan rakyat, sejarah intelektual, sejarah keluarga, sejarah etnis, sejarah psikologi, psikologi histori, sejarah pendidikan dan sejarah medis.

Kartodirdjo mengemukakan bahwa sejarah mempunyai kegunaan genetis dan kegunaan didaktik. Pada kegunaan genetis, nilai-nilai luhur yang terdapat pada setiap peristiwa masa lampau perlu diwariskan secara turun-menurun agar dapat membentuk watak manusia sesuai dengan harkat dan martabatnya sebagai manusia. Sedangkan sebagai kegunaan didiaktik atau pendidikan nilai- nilai luhur yang terdapat pada peristiwa masa lampau perlu diwariskan kepada generasi muda agar dapat mengembangkan seluruh potensi yang dimilikinya. Memperhatikan kegunaan tersebut, secara instrinsik dapat dikemukakan bahwa sejarah memiliki kegunaan edukatif atau pendidikan dan kegunaan instruktif atau memberikan pengajaran (Kartodirdjo, 1992).

\section{KESIMPULAN}

Ilmu Pengetahuan Sosial adalah mata pelajaran di sekolah yang di desain atas dasar fenomena, masalah dan realitas sosial dengan pendekatan interdisipliner yang melibatkan berbagai cabang ilmu-ilmu sosial dan humaniora seperti kewarganegaraan, sejarah, geografi, ekonomi, sosiologi, antropologi, pendidikan. Karena itu, IPS dapat dikatakan sebagai studi mengenai perpaduan antara ilmu-ilmu dalam 
rumpun ilmu-ilmu sosial dan juga humaniora untuk melahirkan pelaku-pelaku sosial yang dapat berpartisipasi dalam memecahkan masalah-masalah sosio kebangsaan. Bahan kajiannya menyangkut peristiwa, seperangkat fakta, konsep dan generalisasi yang berkait dengan isu-isu aktual, gejala danmasalahmasalah atau realitas sosial serta potensi daerah.

Sebutan IPS di Indonesia adalah sebuah kesepakatan untuk menunjuk istilah lain dari social studies. Menunjuk sifat keterpaduan dari ilmu-ilmu sosial atau integrated social sciences. Jadi sifat keterpaduan itu mestinya menjadi ciri pokok mata kajian yang disebut IPS. IPS adalah studi integratif tentang kehidupan manusia dalam berbagai dimensi ruang dan waktu dengan segala aktivitasnya. Dalam rumusan yang lain, IPS merupakan kajian yang terkait dengan kehidupan sosial kemasyarakatan berserta lingkungannya untuk kepentingan pendidikan dan pembentukan para pelaku sosial.

IPS sebagai mata pelajaran dan pendidikan disiplin ilmu seyogianya memiliki landasan dalam pengembangannya, baik sebagai mata pelajaran maupun pendidikan disiplin ilmu. Landasan berfungsi untuk memberikan pemikiran-pemikiran mendasar tentang pengembangan struktur, metodologi, pemanfaat PIPS sebagai pendidikan disiplin ilmu. Landasan-landasan IPS sebagai disiplin ilmu meliputi Landasan filosofis, Landasan ideologis, Landasan sosiologis, Landasan antropologis, Landasan kemanusian, Landasan politis, Landasan psikologis, Landasan religius. IImu Pengetahuan Sosial berhubungan dengan ilmuilmu Sosial karena IPS dikembangkan ke dalam beberapa ilmu-ilmu sosial. Bidang ilmu tersebut antara lain sosiologi, geografi, ekonomi, sejarah, dan lain sebagainya.

Ilmu pengetahuan sosial (IPS) merupakan suatu kajian pengetahuan yang mencakup empat dimensi yaitu Dimensi Pengetahuan (Knowledge), Dimensi Keterampilan (Skill), Dimensi Nilai dan Sikap (Values And Attiudes), Dimensi Tindakan (Action).

\section{DAFTAR PUSTAKA}

Absor, N. F. (2020). Penggunaan Konstruksi dan Konsensus dalam Kebenaran Sejarah. Prosiding Seminar Nasional Penguatan Riset Dan Luarannya Sebagai Budaya Akademik Di Perguruan Tinggi Memasuki Era 5.0, 304310. Jakarta: Universitas Muhammadiyah Prof. DR. HAMKA. Retrieved from https://proceedings.uhamka.ac.id/index.php/s emnas/article/download/192/169

Cokrodikardjo, M. (2009). Pengertian IPS. Jakarta: Bumi Aksara.

Endayani, H. (2017). Visi Pembelajaran IPS yang Powerful. IJTIMAIYAH, 2(2), 1-16.

Endayani, H. (2018). Sejarah dan Konsep Pendidikan IPS. Ittihad, 2(2), 117-127. Retrieved from http://ejournalittihad.alittihadiyahsumut.or.id/index.php/ittiha d/article/viewFile/43/36

Gunawan, R. (2016). Pendidikan IPS: Filosofi, Konsep \& Aplikasi. Bandung: Alfabeta.

Karim, A. (2014). Sejarah Perkembangan IImu Pengetahuan. Fikrah, 2(1), 273-289.

Kartodirdjo, S. (1992). Pengantar Sejarah Indonesia Baru: 1500-1900 dari Emporium sampai Imperium. Jakarta: Gramedia Pustaka Utama.

Kuntowijoyo. (2013). Pengantar IImu Sejarah (Cetakan 1). Yogyakarta: Tiara Wacana.

Lubis, M. A. (2018). Konsep Dasar IPS. Yogyakarta: Samudra Biru.

Madjid, M. D., \& Wahyudhi, J. (2014). IImu Sejarah: Sebuah Pengantar. Jakarta: Prenada Media Grup.

Miftahuddin. (2016). Revitaslisasi IPS dalam Perspektif Global. Jurnal Pemikiran 
Volume 3 Nomor 2, bulan November, tahun 2021: hal $89-99$

Keislaman, 27(2), 267-284.

https://doi.org/10.33367/tribakti.v27i2.269

Moleong, L. J. (2018). Metode Penelitian Kualitatif (Cetakan 38). Bandung: PT Remaja Rosdakarya.

Muniroh. (2020). Rangkuman Pendidikan IPS di $S D$. Depok: Universitas Terbuka.

Nofiaturrahmah, F. (2015). Pelajaran IImu Pengetahuan Sosial Untuk Mi Yang Menyenangkan. Elementary, 3(2), 221.

Segara, N. B., Pasya, G. K., \& Maryani, E. (2016). Kontribusi Pemahaman Konsep Geografi Terhadap Sikap Dan Perilaku Keruangan Peserta Didik Sma Di Kota Cirebon. Jurnal Geografi Gea, 12(2), 28-36. https://doi.org/10.17509/gea.v12i2.1782

Wahana, P. (2016). Filsafat IImu Pengetahuan. Yogyakarta: Pustaka Diamond. 